\title{
Aesthetic Perception of Urban Streetscapes and the Impact of Form-Based Codes and Traditional Zoning Codes on Commercial
} Signage

\author{
Pat Crawford, Eunsil Lee, Maleah Beatty \\ School of Planning, Design \& Construction, Michigan State University, East Lansing, USA \\ Email: crawf203@msu.edu
}

Received 15 June 2015; accepted 29 August 2015; published 1 September 2015

Copyright (C) 2015 by authors and Scientific Research Publishing Inc.

This work is licensed under the Creative Commons Attribution International License (CC BY). http://creativecommons.org/licenses/by/4.0/

\section{(c) (i) Open Access}

\begin{abstract}
The use of form-based codes for commercial signage regulation, as an alternative to conventional zoning codes, is a growing conversation with planners, designers, lawyers and the sign industry. The purpose of this study is to address a knowledge gap in the conversation-how different signage code applications impact users' aesthetic perceptions of urban streetscapes. This study evaluates aesthetic perceptions of alternative streetscapes depicting form-based codes, traditional zoning codes, and no codes in terms of sense of beauty, interest, and order. One hundred and sixty six respondents rated their perceptions of alternative streetscape signage designs and their responses were compared across the four study nodes in the study. The findings revealed significant differences in respondents' aesthetic perceptions of beauty, interest, and order among streetscape alternatives with form-based codes, traditional zoning codes, and no code applications. The streetscape with form-based codes was perceived as the most beautiful and interesting followed by the ones with zoning codes. Findings indicate that development of a model form-based code may enhance positive perceptions of beauty and interest across different downtown street signs. Respondents' perception of order varied by landscape type, showing lower sense of order for formbased code applications in the corporate area, while higher sense of order in the downtown business area. Findings can inform interdisciplinary discussions on planning code development, signage design and urban streetscape design.
\end{abstract}

\section{Keywords}

Form-Based Codes, Aesthetic Perception, Signage, Urban Streetscape 


\section{Introduction}

Developing from New Urbanism, form-based codes have been used since the early 1980s as an effective urban design guideline and as an alternative design tool for conventional zoning codes across the US (Parolek, Parolek, \& Crawford, 2008). Conventional zoning codes have traditionally focused on the protection of public health, safety, and welfare by separating residential land use from industrial or commercial uses (Parolek, et al., 2008). However, for decades the inflexibility of zoning codes, which segregate the development by land use into residential, commercial, and industrial categories, has been criticized for its negative impacts on the built environment (Jourdan, Hurd, Hawkins, \& Winson-Geideman, 2013).

In response to the limitations of zoning codes, many techniques like alternative codes, form-based codes, and smart codes have emerged to challenge the concept of segregated development found in traditional zoning codes (Power, 2007). The primary emphasis of form-based codes is to shape the physical form of the built environment to create a good urban design and architectural character by focusing on design rather than use (Chicago Metropolitan Agency for Planning (CMAP), 2013; Form-Based Code Institute, 2014; Parolek et al., 2008).

Commercial signage, which plays an important role in urban design, has traditionally been governed by a municipality's zoning code. By treating the signs as land use, rather than as a form of commercial communication, the application of zoning codes on commercial signage has given rise to several issues and areas of debate. Among these are visual clutter, disorganization in development patterns, and disputes over signage regulations (Jourdan et al., 2013; Kinoshita \& Orlando, 2013).

With the growing popularity of form-based codes as a supplement for the traditional zoning code, the impacts of form-based codes on urban settings have attracted more research interest (Parolek et al., 2008). Studies have demonstrated the effects of form-based codes on urban planning and design (Wei, 2011), walkability (Daley, 2010; Hansen, 2014), sustainability (Kim, 2010; Senbel, van der Laan, Kellett, Girling, \& Stuart, 2013), sense of community (Simpson, 2010; Walters, 2011), and legal issues (Geller, 2010; Lawlor, 2010).

Previous studies have extensively investigated various aspects of signage, such as effects of signage on business (Kim, 2010; Morris, Hinshaw, Mace, \& Weinstein, 2001; Rexhausen, Hildebrandt, \& Auffrey, 2012; Snyder, 2011), way finding (Dogu \& Erkip, 2000; O’Neil, 1991; Tzeng, \& Huang, 2009; Vilar, Rebelo, \& Nonega, 2012), and people's behaviors and activities (Bungum, Meacham, \& Truax, 2007; Ford \& Torok, 2008; Sanford \& Finlay, 1988; Turley \& Milliman, 2000). However, few researchers have examined the effects of a form-based signage code on urban streetscapes compared to traditional zoning code applications. Although different sign codes can affect not only the visual but also the functional quality of urban streetscapes, little research has focused on how people perceive sign designs based on different signage regulations.

Considering that the lack of empirical data to support signage regulations is the major criticism of current sign law (Jourdan et al., 2013), it is critical to identify the impact of form-based codes and traditional zoning codes on people's perceptions of streetscapes. To fill this research gap, the present study identifies how different signage code applications affect users' aesthetic perceptions of urban streetscapes. Specifically, this study evaluates users' aesthetic perceptions of beauty, interest, and order toward alternatives of streetscapes depicting form-based codes, traditional zoning codes and no codes. The findings are expected to provide insights and an empirical knowledge base for policy makers, planners, designers, business owners, and sign manufacturers to help the development of improved model sign codes which take into account the perceptions of different stakeholder groups.

\section{Literature Review}

\subsection{Form-Based Signage}

Conventional zoning, commonly referred to as Euclidean zoning, has dominated the development of land throughout the US since the middle of the 20th century. Conventional zoning codes are intended to protect the health and welfare of residents by setting clear boundaries between residential areas and industry to lower negative impacts on housing quality (Barnett, 2003; Burdette, 2004; Kettren, et al., 2010; Parolek et al, 2008; Purdy, 2006). Conventional zoning has been criticized for lack of design consideration, inefficient land use and serious social segregation since the 1960s (Carmona, 2009).

Unlike conventional land use-based zoning, form-based code is a method of regulating urban development that focus less on land use, and more on physical form and appearance (CMAP, 2013). Seeking an alternative to zoning codes, a group of planners and architects created form-based codes in the 1980s, which address the relationships between buildings and the surrounding community (i.e., street, pedestrians, vehicles, and public and 
private spaces), and the scale and types of streets and blocks (Katz, 2005).

Form-based code is defined by the Form-Based Codes Institute as: "A land development regulation that fosters predictable built results and a high-quality public realm by using physical form (rather than separation of uses) as the organizing principle for the code". Form-based codes are a type of land development regulation which focuses on design within the public realm. These types of codes aim to create a cohesive relationship between forms within the built environment, including streetscapes, architecture, civic spaces and neighborhoods. This is accomplished through clearly described regulations, diagrams, images and maps found within each code. By using both graphic and text reference, the code becomes simple to interpret for users in both the private and public sector. A form-based code describes the vision created by a community and provides developers with the tools becoming part of that vision. The simple nature of a form-based code decreases misunderstandings between municipalities and developers and fosters predictable built results for more efficient growth (Form-Based Codes Institute, 2015; Parolek et al., 2008; Rangwala, 2012).

Table 1 presents the major differences between conventional zoning and form-based codes. Although both zoning and form-based codes are designed to protect public health, safety, and welfare, by strictly segregating the land uses, zoning codes have failed to encourage a sense of community. Form-based codes promote integration of community and the creation of a more livable environment through emphasizing mixed-use development based on the context of building form, scale and type. Conventional zoning codes focus on uniformity of a district with a one-size-fits-all approach to regulation. Form-based codes focus more on diversity in the community with detailed and locally specific regulation language that addresses site design and building form. Form-based codes provide more detailed guidelines of building forms and streetscapes by suggesting unique ways to create a public realm with visual diagrammatic standards.

Where conventional zoning codes focus on the lot and dimensional requirements, form-based codes provide a more holistic way to develop a desired urban form by considering building form related to the streetscape, taking into consideration the scale and style of a structure in relation to the surrounding built forms and pedestrian environment. Form-based codes create a walkable, pedestrian-friendly, and interactive community and provide a means to represent the community's vision by encouraging public participation through community workshops or design charrettes (CMAP, 2013; Purdy, 2006).

In contrast, the major weaknesses of form-based codes are the time and cost to achieve the benefits of formbased codes. This stems from a lack of understanding about form-based codes and the fear of change among developers and planners, in addition to the long process of obtaining final approval for development (CMAP, 2013). Due to the upfront work to develop a community inventory of current urban form and create the plans and codes, form-based codes cost two to four times more than conventional zoning (Purdy, 2006). The prescriptive guidelines of form-based code are also perceived as limiting architects' creativity and developers' options (Purdy, 2006).

\subsection{Signage Regulation}

Since the early 1900s, commercial sign controls have been used to preserve public health and safety by ensuring visibility for traffic, reducing distractions, and ensuring quality construction and implementation of signs (Jourdan et al., 2013). Traditionally, a municipality's zoning code has governed commercial sign controls, but form-based codes are increasingly used in new forms of sign regulation (Parolek et al., 2008). The objective for both codes is to organize signage in a way that promotes health, safety, and general welfare, but they differ in

Table 1. Key differences between conventional zoning codes and form-based codes (adapted from Parolek et al. (2008)).

\begin{tabular}{cc}
\hline Conventional Zoning Codes & Form-Based Codes \\
Use is primary & Physical form and character are primary \\
Segregated land-use & Mixed use \\
Auto-oriented & Walkable and compact development-oriented \\
Organized around single-zones & Reinforce an urban hierarchy (e.g., rural-to-urban transect) \\
Reactive to individual development & Proactive community visioning \\
Regulates to create buildings & Regulates to create places \\
Proscriptive regulations: Regulate what is not permitted & Prescriptive regulations: Describe what is required
\end{tabular}


their application and in the predictability of the manifestation of the code.

Since commercial signs play a significant role in the visual quality of urban streetscapes, effective application of commercial signage controls is critical to decrease the negative consequences of commercial signs, such as visual pollution, increased user satisfaction and positive perceptions of urban streetscapes (Portella, 2014). Although different sign controls can produce a range of results, the ways in which users perceive these differing sign controls has undergone little exploration. Today's commercial signage is not based on users' perceptions. The lack of empirical data to support these controls can lead to disputes about free speech and overreaching regulation (Jourdan et al., 2013; Kinoshita \& Orlando, 2013).

While little empirical evidence of universal views of users toward commercial signage controls has been shown in previous research, Portella's $(2007,2014)$ recent studies on signage and environmental quality shed some light on common visual preferences of signage across users from different urban context. Through extensive case studies of three historic cities in the UK and Brazil, Portella found there were universal perceptions among users across cultures and professions toward a variety of characteristics of signage and its relation to historic downtowns. Portella's $(2007,2014)$ study suggests a general signage control can be developed and applied over large geographic areas by verifying common user preferences which can lead to the creation of effective and appealing signage regulation.

\section{Aesthetic Perception of Urban Streetscape}

The evaluation of landscape aesthetic quality has been a major theme of landscape research for decades (e.g., Liu \& Burley, 2013, Matsuoka \& Kaplan, 2008; Palmer, 2000; Stamps, 2004). The aesthetic quality of landscapes has traditionally been assessed through expert or perception-based approaches. An expert-based approach evaluates aesthetic quality objectively by qualified professionals, but the reliability of evaluation has been called into question. The perception-based approach evaluates the aesthetic quality of environments by studying responses of users (non experts). Although the perception-based approach has been viewed as controversial or problematic (Scott, 2002), the perception-based approach has been the major evaluation method used in landscape research. Assessing and incorporating public perception of landscapes has been considered important in landscape research as well as in policy making (Real, Arce, \& Sabucedo, 2000; Scott, 2002). As aesthetic judgment of urban landscape plays an important role in people's emotional well-being (Galindo \& Rodriguez, 2000) and as interest in environmental quality grows, the importance of landscape quality evaluation for the general public becomes greater (Real et al., 2000).

A fundamental aspect of landscape aesthetics is the perception of beauty (Lang, 2005, 2007; Nohl, 2001). People perceive the landscape as beautiful when all elements are balanced and ordered without excessive variety and diversity (Sieferle, 1986). The perception of beauty is closely related to the state of order. Traditionally, when everything is in unity and harmony as a part of the whole, people perceive the landscape as beautiful (Kaplan \& Kaplan, 1989). The aesthetic category of interesting plays an important role in urban-industrial landscape areas (Nohl, 2001). The perception of something being interesting differs from the beautiful, in which order is directly related. The aesthetic perception of interesting can be greater when more relationships are involved and in positive way even with things are ugly, chaotic, or confusingly complicated (Nohl, 2001).

In studying commercial signage, Portella (2014) analyzed aesthetic judgment of the physical characteristics of buildings and signage by measuring user perceptions in terms of beauty, interest, and order. The study found that the variation of commercial signs and buildings affect user perception and evaluation of beauty, interest, and order. According to Portella (2014), higher variation of commercial signs and buildings with lack of order was negatively perceived by users from different urban contexts while lower variation in commercial signage was related to higher level of beauty, interest, and order. Portella (2014) indicated that order was an important factor in good streetscape design because order keeps signs visible and decreases distraction along a streetscape.

According to Portella (2014), the characteristics of commercial signs influencing user perceptions include size of signs, discrete commercial signage, legibility, color, number of commercial signs, and the coverage of street façade. Portella (2014) also indicated that user perception and evaluation of beauty, interest, and order were significantly influenced by resident's familiarity with the streetscape.

\section{Study Hypothesis}

Given that signage codes can influence the visual aesthetics of commercial signage and urban streetscapes, we 
hypothesized that signage design with different signage codes (form-based code, traditional zoning code, and no code application) will be perceived differently by users. Based on three dimensions of aesthetic qualities (Portella, 2014): beauty, interest, and order, three hypotheses are formulated:

H1. There are significant differences in the user's perception of beauty toward streetscape alternatives with form-based codes, traditional zoning codes, and no code applications

H2. There are significant differences in the user's perception of interest toward streetscape alternatives with form-based codes, traditional zoning codes, and no code applications

H3. There are significant differences in the perception of order toward streetscape alternatives with formbased codes, traditional zoning codes, and no code applications

Methodology

\subsection{Research Site}

The study area includes a portion of the Greater Lansing area, which is centrally located in the Michigan Lower Peninsula. Both the City of Lansing and East Lansing are included in the research site (see the Figure 1). The City of Lansing is home to Michigan's capital and approximately 113,996 residents. The 36.68 square mile city supports many industries including health care, public administration, educational services, and construction (City Data, 2012). With a 7.3\% unemployment rate and a median household income of $\$ 33,514$, the economic standing of the City sits just below the state average (City Data, 2012; United States Bureau of Labor Statistics, 2014). The City has adopted the Design Lansing Comprehensive Plan, as well as being selected by the Environmental Protection Agency (EPA) to be part of the Greening America's Capitals initiative in an effort to bring positive change to the area (City of Lansing, 2012).

US-127 Highway divides Lansing from nearby East Lansing, another section of the Greater Lansing study area. East Lansing is small, both in area and population. The city occupies an area of 13.67 square miles with an approximate population of 48,518 (City Data, 2012). Because East Lansing is the home of Michigan State University, the student population fluctuates greatly during the school year. While the unemployment rate in East Lansing is a little lower than the City of Lansing, the median household income is lower as well. Educational service is the dominant industry in the area, followed by accommodation and food services, healthcare and social assistance (City Data, 2012).

The Greater Lansing area is connected by many natural features and thoroughfares, but the Grand River/Michigan Avenue corridor is a primary artery linking the City of Lansing and East Lansing. This study concentrates on four nodes along this artery, spanning from downtown East Lansing to the State Capital. Figure 2 presents the locations of the four study nodes on Grand River/Michigan Ave. in Lansing and East Lansing. Figure 3 presents the present streetscapes of node 1 through node 4 with current signage code application.

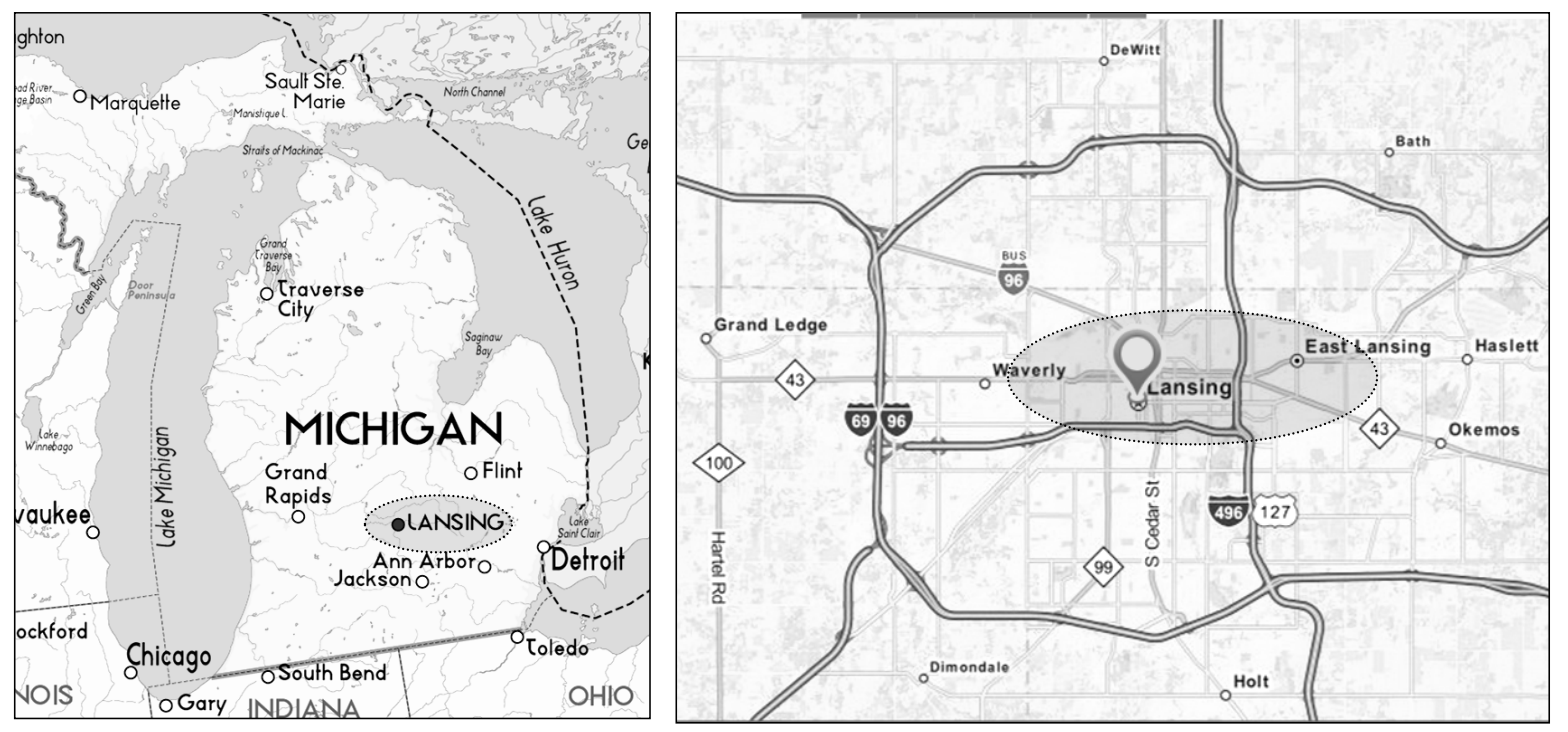

Figure 1. Maps of Michigan and Lansing, MI. 


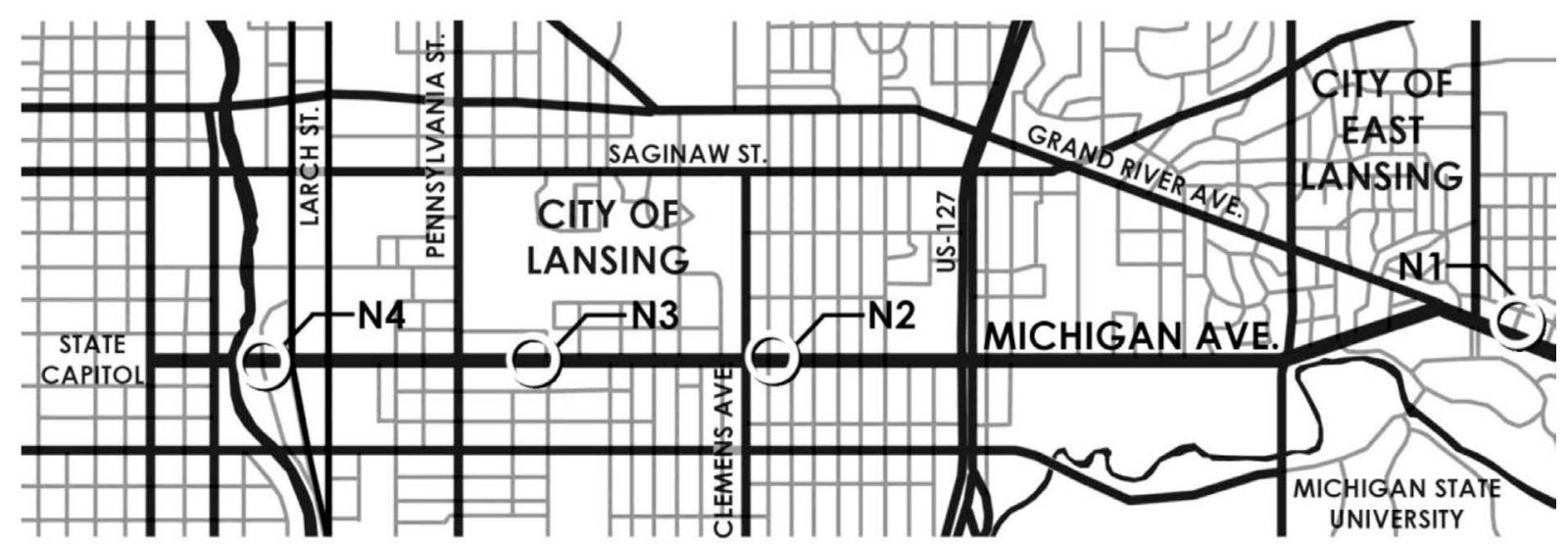

Figure 2. Four study nodes in grand river/Michigan avenue corridor.
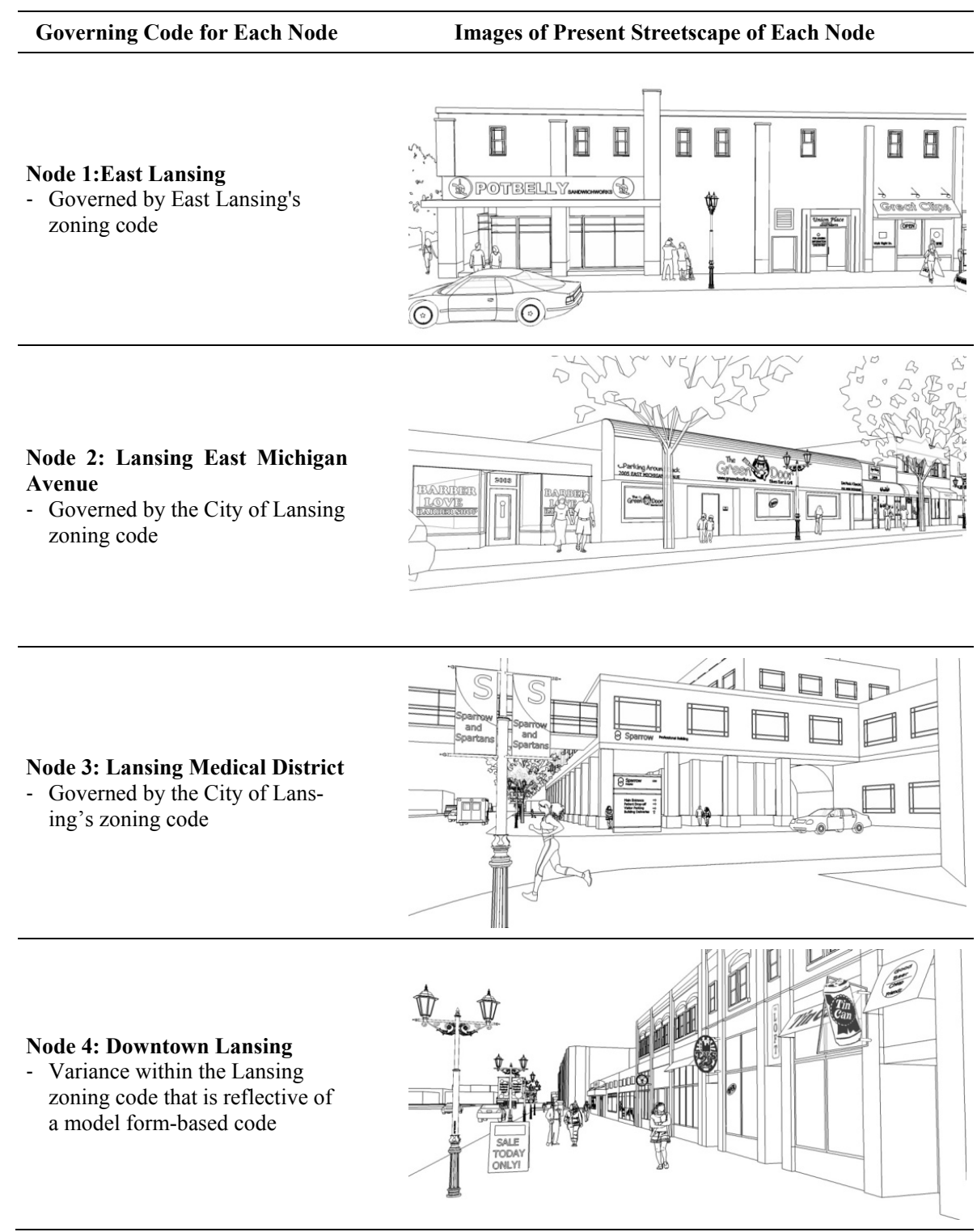

Figure 3. Line drawing images of four study nodes showing existing streetscapes. 
Node 1: East Lansing. The signage in Node 1 is governed by East Lansing's zoning code and is zoned as a C parcel. Chapter 32 of the City of East Lansing's code of ordinances outlines the code governing signs along with three additional regulations (East Lansing, 2014). The existing sign code in this area seems to be well enforced with few signs in poor condition. The bulk of non-conforming signs include electronic message centers (EMC). This is due to the recent passing of a sign ordinance which put a ban on these specific signs. All of the grandfathered EMC signs that have been cataloged seem to be fairly new and in good condition.

Node 2: Lansing East Michigan Ave. The signage in Node 2 is governed by the City of Lansing zoning code and is zoned as an F-1 parcel for commercial use. Zoning regulations governing signs in this node can be found in the City of Lansing Zoning Ordinance part 14, and is supported by a variety of permit applications and informational web pages on the City of Lansing's website (Lansing, 2014). The existing sign code does not seem to be well enforced in this area. Many signs are in poor condition and there are several instances of non-conforming signs along Michigan Avenue. The Lansing East Michigan Avenue node has the dynamic of a neighborhood downtown and is accessible to both vehicular and pedestrian traffic, but is less traveled by foot.

Node 3: Lansing Medical District. The signage in Node 3 is governed by the City of Lansing's zoning code and is zoned as a DM-4 parcel for residential-mixed use and as an F-1 parcel for commercial use. Zoning regulations governing signs in the City of Lansing are supported by a variety of permit applications and informational web pages on the City of Lansing's webpage (Lansing, 2014). The sign code in this area seems to be well enforced and few signs are in poor condition. This area has been described as lacking character and appearing cold or sterile (Witter \& Crawford, 2013). The Lansing Medical District node has the appearance of a corporate landscape and is accessible to both vehicular and pedestrian traffic, but is primarily traveled by automobile.

Node 4. Downtown Lansing. The signage in Node 4, Downtown Lansing, is zoned as a G-1 parcel for business use (Lansing, 2014). The Downtown Lansing node has the dynamic of a city downtown and is well used by both vehicular and pedestrian traffic. The purpose and intent of the Capitol Center District is to place more restrictive sign regulation on the area associated with the Michigan State Capitol Building. This is a unique area within the State and the City, and has sign regulations that intend to preserve vistas, protect the dignity and enhance the visual cityscape of the Capitol. This area has a variance within the Lansing zoning code that specifically applies to the downtown and is expressed in the City of Lansing Zoning Ordinance- Part 14- Building \& Housing Code- Title 4- Miscellaneous Building Regulations- Chapter 1442.23 Capitol Center District (Lansing, 2014). The language in this chapter is reflective of a model form-based code. As stated by the code:

Buildings in the capitol center district that are used for a public purpose and are owned or entirely occupied by the United States Federal Government, State of Michigan or the City of Lansing and any of its Agencies, Departments or instrumentalities are exempt from the dimensional requirements of the code. The Director of the Department of Planning and Neighborhood Development has sole authority to approve or deny signs for these agencies after reviewing the proposed sign's compatibility with the surrounding area and the goals expressed in the code (Lansing, 2014).

\subsection{Sampling and Data Collection}

The target population for this study includes stakeholder groups such as home and business owners, students, government affiliates, institutional affiliates, planning and design professionals and sign manufacturers. A convenience sampling strategy was used to recruit a wide range of participants based on availability. A self-administered online survey was conducted via Survey Monkey (Michigan State University IRB \#14-159). An email invitation with a link to the survey was sent to potential subjects of the study through various organizational listservs including the Signage Foundation Inc. An announcement with a link to the online survey was also posted on the websites of the Signage Foundation Inc. and the International Sign Association. Social networking sites were also used to contact potential participants. In total, 166 surveys were used in the analysis after incomplete surveys were excluded.

\subsection{Measurement and Instrument}

To measure users' aesthetic perceptions toward different signage control systems, this study utilized an in-situ approach to preserve the original quality of the four study nodes (Appendix 1: Images of Survey Monkey Instrument). Visual images were created to represent three signage control systems: form-based code, zoning code, and no code or controls. Figures 4-7 present the four study nodes and images of the signage code applications 
used for comparison in the survey.

To create the images showing an existing and altered streetscape with the different sign code applications, Sketch Up models were created using black and white line drawings to keep the images clear and concise.

Photographs and hand drawn images are commonly used in the evaluation of landscape aesthetic quality; however, photographs could pose a problem because the altered images for comparisons would have a photoshopped appearance. This would indicate to the respondent which image was actual and which image had been altered, a factor that can cause bias.

Hand-drawn images could also be problematic, because it has been found that landscape drawings are seen as art, not as an accurate representation of the landscape (Smardon, Palmer, \& Fellemen, 1986). Participants could gauge their preference of the images on the quality of the drawing rather than what the image is representing. Given these limitations, Sketch Up modeling was chosen as an appropriate way to gather accurate and viable data and collect reliable results from participants in evaluating aesthetic perceptions of streetscapes (Partin, 2011: p. 58).

Participants were asked about their impressions of a set of signage designs in the four study nodes along the study corridor. Each set consists of two images of the same streetscape: the present commercial signs and alternative commercial signs with either 1) form-based signage code, 2) conventional zoning signage code, or 3) no signage code. Figures 4-7 show the four sets of comparison streetscape images side-by-side that were used in the survey.

Comparison for Node 1. Figure 4 shows the comparison between the conventional zoning signage code and no signage code for Node 1, East Lansing location. The present streetscape image included wall signs, awning signs, and window signs based on the East Lansing zoning codes. The alternative image was generated to represent no signage code application by including the EMC sign, roof sign, sandwich board, pole sign, and projecting sign which are not permitted in the existing sign codes of East Lansing.

Comparison for Node 2. Figure 5 shows the comparison between the conventional zoning signage code and the form-based code at Node 2, Lansing East Michigan Avenue. The present streetscape image included the large window signs, various wall signs, and different awning signs based on the City of Lansing zoning code. The alternative streetscape image was generated based on Casper's Old Yellowstone Form Based Code. The signage designs and text sizes for awning signs, wall signs, and window signs were transformed in accordance with the form-based codes.

Comparison for Node 3. Figure 6 shows the comparison of Node 3, Lansing Medical District location: the

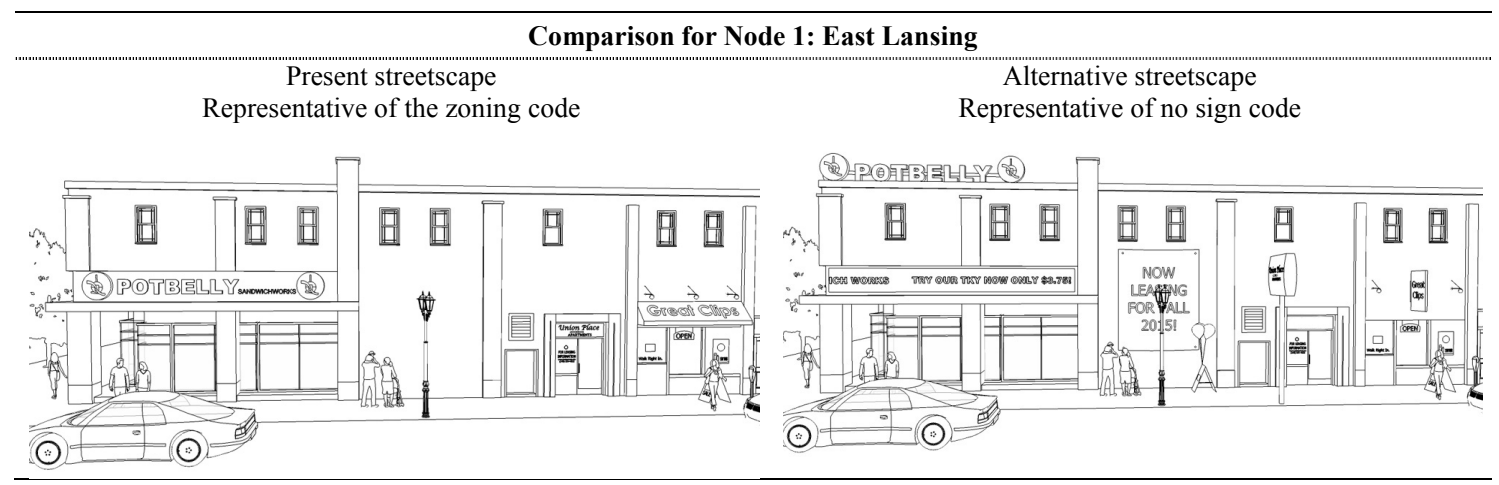

Basis for Alternative Streetscape Images Development: no code application

- EMC sign was added to Potbelly (currently this sign type would not be permitted due to existing sign code)

- Roof Sign was added to Potbelly (currently this sign type would not be permitted due to existing sign code)

- The temporary "Now Leasing" banner was placed, visually filling up the space between Potbelly and Union Place, also giving Union Place more of a presence

- A sandwich board was added with balloons to catch passerby's attention (currently temporary moving or lit objects, like balloons, would not be permitted due to existing sign code)

- Pole and Panel sign was added along the street. Increases visibility along Grand River Rd. and perpendicular signage can be seen from a distance down the street (currently this sign type in combination with the sign's proximity to the building, would not be permitted due to existing sign code)

- Great Clips awning was removed and replaced with a projecting sign. More visible for two way foot and auto traffic (currently this sign type would not be permitted due to existing sign code)

Figure 4. Comparison for node 1: zoning code vs. no code application. 


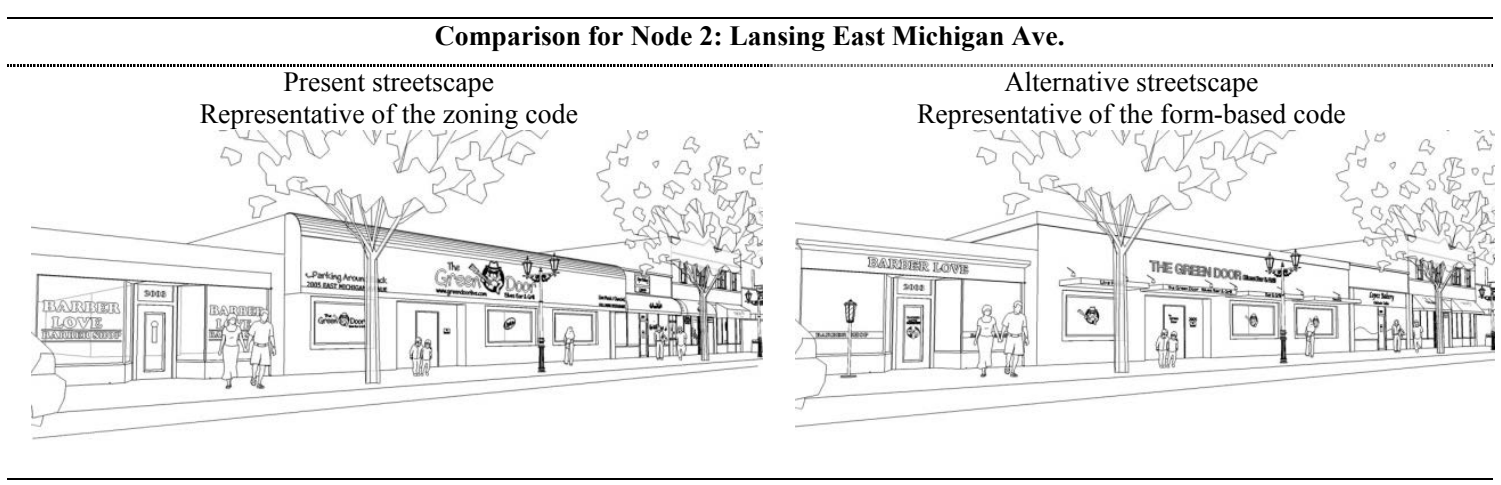

Basis for Alternative Streetscape Images Development: Form-based Code Application

- Based on Casper's Old Yellowstone District Form Based Code

- Zone 2. Areas coded for this zone are secondary in intensity and, are intended to support the bulk of the commercial and business ground floor uses within the Old Yellowstone District and South Poplar Street Corridor. Building types include perimeter block, stacked flats, courtyard, and parking buildings.

- Awning Signs

Awnings are limited to first and second floor uses only. Awnings shall be mounted on the building in such a way that they project over individual windows and door openings.

- Backlit, translucent, internally illuminated awnings are prohibited.

- Sign area or sign lettering shall comprise no more than thirty percent $(30 \%)$ of the total exterior surface of an awning. Any graphic logo or text printed on an awning will be counted toward the total maximum allowable sign area.

- Wall Signs

○ Wall signs shall not project from the surface upon which they are attached more than twelve inches (12").

- Wall signs and "ghost" signs painted directly on a structure are appropriate.

- The maximum total wall signage per façade shall not exceed two (2) square feet per linear foot of building façade length of the wall on which it is to be located. In no case shall total wall signage exceed a maximum of three hundred (300) square feet for any building.

- Window Signs

Window signs shall not cover more than twenty-five percent $(25 \%)$ of the area of each window.

Figure 5. Comparison for node 2: zoning code vs. form-based code application.

conventional zoning signage code versus form-based code. The present streetscape image included the freestanding signs, street banners, and wall signs based on the City of Lansing zoning code. The alternate image was generated based on Casper's Old Yellowstone Form Based Code. The text sizes and signage designs were transformed in accordance with the guidelines of form-based codes.

Comparison for Node 4. Figure 7 shows the comparison between the form-based signage code and no signage code at Node 4, Downtown Lansing location. The present streetscape image included the awning signs, projecting signs, street banners, window signs, and wall signs based on the City of Lansing Building and Housing Code for Capitol Center District which is similar to the form-based codes. The alternative image was generated for the no code application by creating an everywhere USA generic character. Various sign designs which are not permitted in the form-based codes such as enlarged text size, post signs, wall mounted signs, and large billboards were included.

To measure three dimensions of aesthetic perception: beauty, interest, and order, respondents were shown one image of the streetscape at a time, and asked to rate the extent to which they perceived the streetscape as being beautiful, interesting, and ordered. The responses were ranked along a 5-point Likert-scale from 1 (very ugly, very boring, and very chaotic) to 5 (very beautiful, very interesting, and very ordered). The survey also asked about participant demographic information such as age, gender, major stakeholder affiliation, and education.

\section{Results}

\subsection{Respondent Profiles}

Table 2 shows the demographic information of survey respondents. Approximately 19\% were between 18 and 29 years old; $37 \%$ were in their $30 \mathrm{~s}$ and $40 \mathrm{~s} ; 42 \%$ were in their $50 \mathrm{~s}$ and $60 \mathrm{~s}$; and $2 \%$ were over 70 . About $37 \%$ were male and 63\% were female. Most of the respondents $(89.9 \%)$ had at least a bachelor's degree, and two-thirds had earned a master's degree or higher (61\%). In terms of stakeholder affiliation, approximately $43 \%$ 


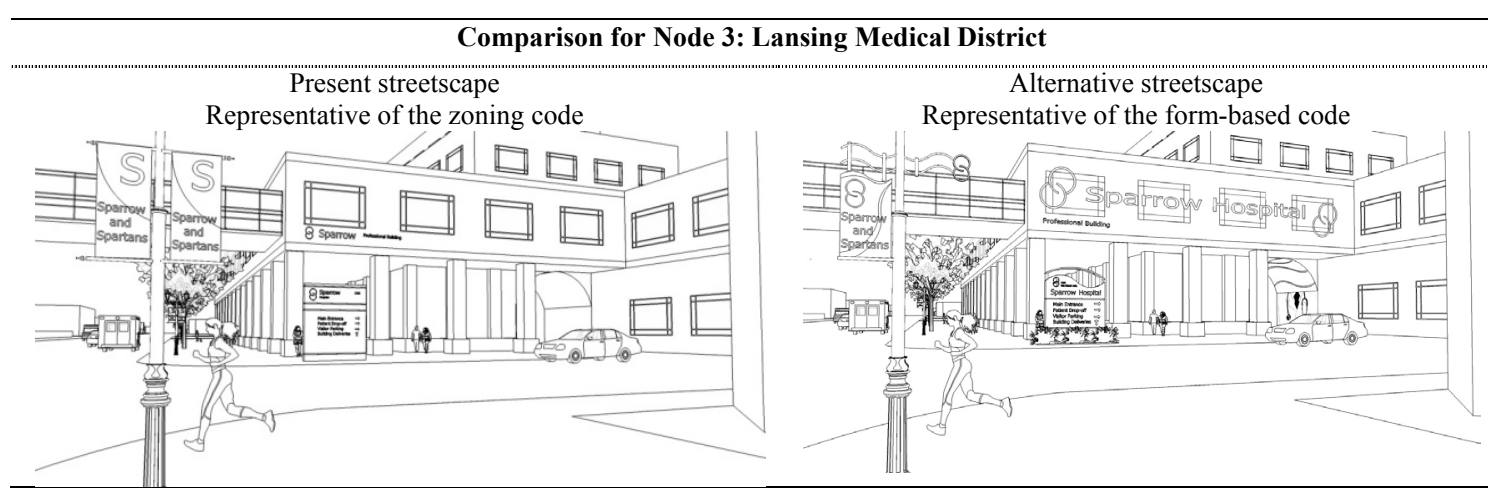

Basis for Alternative Streetscape Images Development : Form-based Code Application

- Based on Casper's Old Yellowstone District Form Based Code

- Zone 1: This zone is the most intensive development area and is most appropriate for multi-story mixed-use buildings with ground floor offices and commercial. Building types include podium tower, perimeter block, stacked flats, icon structures and parking buildings.

- Street Banners

- Although street banners are not mentioned specifically in either the lighting or sign sections of the code, examples of street banners are shown in the lighting section, which we interpreted that they may not be regulated, but an acceptable form of signage.

- Lighting Objective: To ensure quality lighting design through glare reduction, minimum overspill and the use of fixtures that promote the existing character.

- Freestanding/Monument Sign

- The maximum number of free-standing signs is one (1) per street frontage.

- All free standing signs shall be monument-type (solid base). Pole and pylon signs are prohibited.

- Monument signs may be internally illuminated, however, the sign copy should be the only portion of the sign face that is illuminated. The sign background or field should be opaque with a non-gloss, non-reflective finish.

- Monument signs shall be placed perpendicular to the street, and so they do not obstruct sight lines at driveways or intersections.

- Monument signs shall incorporate landscaping at their base, in accordance with the landscaping regulations found in the Appendix of the Old Yellowstone District and South Poplar Street Corridor Form-Based Code.

- Monument signs shall conform with the following: Max height-8', Max Area 50 sq.ft.

- Building Wrap

- This sign type has not been specified or regulated within the model code but does follow the guidelines of the General Standards subsection.

- Wall Sign/Mural

- Wall signs shall not project from the surface upon which they are attached more than twelve inches (12").

- Wall signs and "ghost" signs painted directly on a structure are appropriate.

- The maximum total wall signage per façade shall not exceed two (2) square feet per linear foot of building façade length of the wall on which it is to be located. In no case shall total wall signage exceed a maximum of three hundred (300) square feet.

\section{Figure 6. Comparison for node 3: zoning code vs. form-based code application.}

of the respondents were working as planning or design professional; About $16 \%$ identified as homeowners; $14.5 \%$ identified as students; about $10 \%$ identified with an institution affiliation; about $8 \%$ identified as sign manufacturers; and about $6 \%$ were business owners, developers or rental property owners.

\subsection{Hypothesis Testing}

Paired sample $t$-tests were conducted to test the three hypotheses to identify whether there are differences in respondents' aesthetic perceptions toward streetscapes with different signage code applications. The results are presented in Tables 3-5.

\subsection{Beauty}

Hypothesis 1 tested whether there are significant differences in users' perception of beauty between two streetscapes with different signage code applications. Results of paired sample t-tests indicated significant mean differences in all the comparisons of the four study nodes (Table 3). The mean scores of beauty for streetscapes with no code applications were significantly lower than the mean scores of both Node 1 , with zoning codes $(t$ $(162)=-5.938, p<0.000)$ and Node 4 , with form-based codes $(t(130)=-10.768, p<0.000)$. In the compare- 


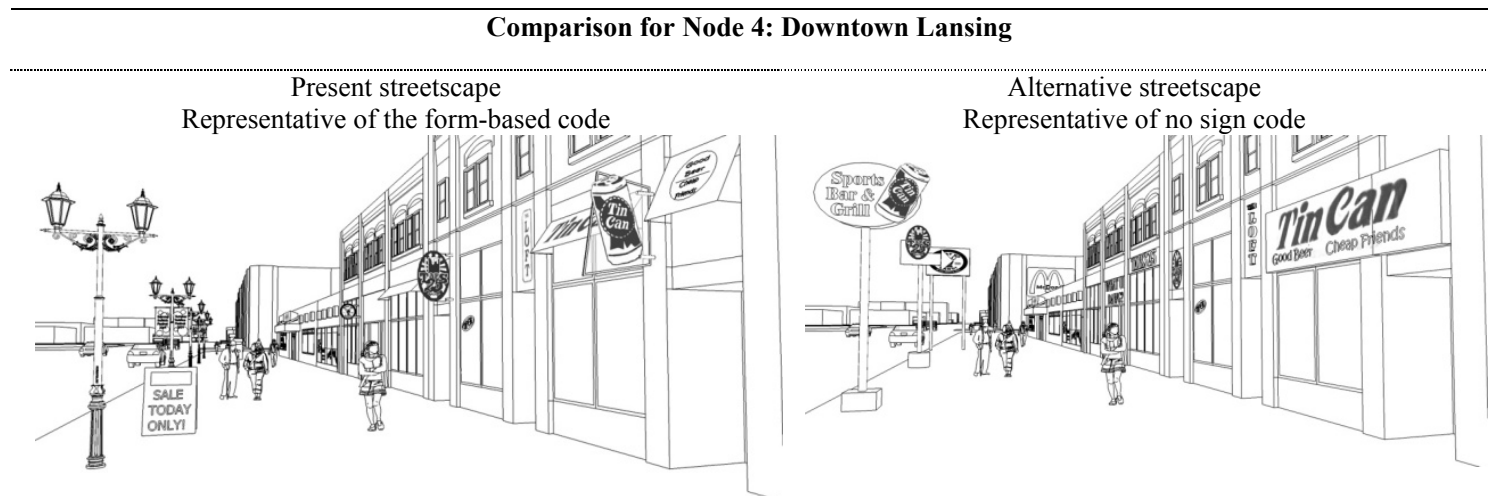

\section{Basis for Alternative Streetscape Image Development : No Code Application}

- Create an everywhere USA-Form a generic character.

- Placement of pole sign signs along street to attract attention from the heavy motor traffic in this downtown area (currently not allowed in this setting/proximity to the pedestrian walkway due to existing sign code).

- The placement of large billboard advertisement.

- The removal of awning signs and projecting signs in favor of wall mounted signs, 3D lettering and cabinet signs.

- Increased scale of building mounted signs, to attract attention from the heavy motor traffic in this downtown area.

- The enlargement of text, increases visibility (currently this scale would not be permitted due to existing sign code).

- Removal of Sandwich board.

Figure 7. Comparison for node 4: form-based code vs. no code application.

Table 2. Percentage distribution of socio-demographic characteristics

\begin{tabular}{|c|c|c|c|}
\hline & & Frequency & Percent $(\%)$ \\
\hline \multirow{5}{*}{ Age $(n=128)$} & $18-29$ & 24 & 18.8 \\
\hline & $30-39$ & 30 & 23.4 \\
\hline & $40-49$ & 17 & 13.3 \\
\hline & $50-59$ & 35 & 27.3 \\
\hline & $60-69$ & 19 & 14.8 \\
\hline \multirow{5}{*}{ Gender $(n=128)$} & $70+$ & 3 & 2.3 \\
\hline & Male & 47 & 36.7 \\
\hline & Female & 81 & 63.3 \\
\hline & Some College & 11 & 8.6 \\
\hline & Associate's Degree & 2 & 1.6 \\
\hline \multirow[t]{3}{*}{ Education $(n=128)$} & Bachelor's Degree & 37 & 28.9 \\
\hline & Master's Degree & 55 & 43.0 \\
\hline & $\mathrm{PhD}$ & 23 & 18.0 \\
\hline \multicolumn{4}{|c|}{ Stakeholder Affiliation $(\mathrm{n}=166)$} \\
\hline \multicolumn{2}{|c|}{ Homeowner } & 26 & 15.7 \\
\hline \multicolumn{2}{|c|}{ Business Owner } & 8 & 4.8 \\
\hline \multicolumn{2}{|c|}{ Rental Property Owner } & 3 & 1.8 \\
\hline \multicolumn{2}{|c|}{ Student } & 24 & 14.5 \\
\hline \multicolumn{2}{|c|}{ Developer } & 1 & 0.6 \\
\hline \multicolumn{2}{|c|}{ Government Affiliation } & 4 & 2.4 \\
\hline \multicolumn{2}{|c|}{ Institution Affiliation } & 16 & 9.6 \\
\hline \multicolumn{2}{|c|}{ Planning/Design Professional } & 71 & 42.8 \\
\hline \multicolumn{2}{|c|}{ Sign Manufacturer } & 13 & 7.8 \\
\hline
\end{tabular}

Note: The numbers vary due to missing responses. 
Table 3. Paired samples t-test estimates for the perception of beauty between commercial signs with different signage code applications in the four nodes of the greater Lansing area.

\begin{tabular}{|c|c|c|c|c|c|}
\hline Nodes (Beauty) & $\mathrm{N}$ & Present Sign (M) & Alternative Sign (M) & $\mathrm{t}$ & Sig. \\
\hline Node 1 & & Zoning Code & No Code & & \\
\hline East Lansing & 163 & 3.092 & 2.693 & -5.938 & .000 \\
\hline Node 2 & & Zoning Code & Form-Based Code & & \\
\hline Lansing Michigan Ave. & 135 & 2.993 & 3.385 & 4.777 & .000 \\
\hline Node 3 & & Zoning Code & Form-Based Code & & \\
\hline Lansing Medical District & 135 & 2.993 & 3.185 & 2.108 & .037 \\
\hline Node 4 & & Form-Based Code & No Code & & \\
\hline Downtown Lansing & 131 & 3.237 & 2.282 & -10.768 & .000 \\
\hline
\end{tabular}

Table 4. Paired samples t-test estimates for the perception of interesting between commercial signs with different signage code applications in the four nodes of the greater Lansing area.

\begin{tabular}{|c|c|c|c|c|c|}
\hline Nodes (Interest) & $\mathrm{N}$ & Present Sign (M) & Alternative Sign (M) & $\mathrm{t}$ & Sig. \\
\hline Node 1 & & Zoning Code & No Code & & \\
\hline East Lansing & 162 & 2.907 & 2.654 & -2.657 & 0.009 \\
\hline Node 2 & & Zoning Code & Form-Based Code & & \\
\hline Lansing Michigan Ave. & 137 & 2.591 & 3.124 & 5.042 & 0.000 \\
\hline Node 3 & & Zoning Code & Form-Based Code & & \\
\hline Lansing Medical District & 135 & 2.593 & 3.519 & 9.461 & 0.000 \\
\hline Node 4 & & Form-Based Code & No Code & & \\
\hline Downtown Lansing & 132 & 3.273 & 3.015 & -2.559 & 0.012 \\
\hline
\end{tabular}

Table 5. Paired Samples t-test estimates for the perception of order between commercial signs with different signage code applications in the four nodes of the greater Lansing area.

\begin{tabular}{|c|c|c|c|c|c|}
\hline Nodes (Order) & $\mathrm{N}$ & Present Sign (M) & Alternative Sign (M) & $\mathrm{t}$ & Sig. \\
\hline Node 1 & & Zoning Code & No Code & & \\
\hline East Lansing & 159 & 3.755 & 3.013 & -8.109 & 0.000 \\
\hline Node 2 & & Zoning Code & Form-Based Code & & \\
\hline Lansing Michigan Ave. & 136 & 3.699 & 3.919 & 3.093 & 0.002 \\
\hline Node 3 & & Zoning Code & Form-Based Code & & \\
\hline Lansing Medical District & 134 & 3.739 & 3.216 & -5.265 & 0.000 \\
\hline Node 4 & & Form-Based Code & No Code & & \\
\hline Downtown Lansing & 131 & 3.573 & 2.489 & -9.579 & 0.000 \\
\hline
\end{tabular}

isons between zoning code and form-based code applications, the mean scores of beauty toward streetscapes with form-based code application were significantly higher than zoning code application at both node 2 ( $t$ (134) $=4.777, p<0.000)$ and node $3(t(134)=-2.108, p<0.05)$. These results indicate that the respondents perceived the commercial signs with form-based code applications as the most beautiful, followed by ones with zoning code, and commercial signs with no code applications were perceived as the least beautiful.

\subsection{Interest}

Hypothesis 2 tested whether there are significant differences in users' perception of interesting between two streetscapes with different signage code applications. Results of paired sample t-tests indicated significant mean differences in all the comparisons of the four nodes (Table 4). Just like the results of beauty, the mean scores of interest for streetscapes with no code application were significantly lower than the mean scores of ones with zoning 
codes (at node $1, t(161)=-2.657, p<0.01$ ) as well as form-based codes applications (at node $4, t(131)=-2.559$, $p<0.05$ ). In the comparisons between zoning code and form-based code applications, the mean scores of interest toward streetscapes with form-based code application were significantly higher than zoning code applications at both node $2(t(136)=5.042, p<0.000)$ and node $3(t(134)=9.461, p<0.05)$. These results indicate that the respondents perceived the commercial signs with the form-based code application as the most interesting followed by ones with zoning codes, while commercial signs with no code applications were perceived least interesting.

\subsection{Order}

Hypothesis 3 tested whether there are significant differences in users' perception of order between two streetscapes with different signage code applications. Results of paired sample t-tests indicated that there are significant mean differences in all the comparisons of the four nodes (Table 5). Just like in the results of beauty and order, the mean scores of order for streetscapes with a no code application were significantly lower than the mean scores of ones with zoning codes (at node $1, t(158)=-8.109, p<0.000$ ) as well as form-based code applications (at node $4, t(130)=-9.579, p<0.000)$. The alternative commercial signs with a no code application were perceived least ordered with the lowest mean ratings $(\mathrm{M}=3013$ at node $1, \mathrm{M}=2.489$ at node 4$)$.

However, in the comparisons between zoning code and form-based code applications, respondents' perception of order varied. The mean scores of order toward streetscapes with the form-based code application were significantly higher than zoning code application at node $2(t(135)=3.093, p<0.01)$ while significantly lower than the zoning code applications at node $3(t(133)=-5.265, p<0.000)$. Considering that node 2 (Michigan Avenue) is a downtown business area while node 3 (Lansing Medical District) is a corporate area, the results suggest that the respondents' sense of order may have depended on the landscape type.

\section{Discussion}

Given that the effects of a form-based signage code on an urban streetscape compared to a conventional zoning code application have not been central to previous signage research, this study explored whether different signage code applications affect users' aesthetic perception of urban streetscapes. Based on digital model images of streetscapes of four study nodes along the Grand River/Michigan Avenue corridor in Lansing and East Lansing Michigan, this study evaluated aesthetic perceptions of commercial signs with form-based code, zoning code, and no signage code applications.

Based on previous studies (Lang, 2005, 2007; Nohl, 2001; Portella, 2014), aesthetic perceptions of signage were measured through three dimensions of aesthetics: beauty, interest, and order. The findings revealed significant differences in users' aesthetic perceptions of beauty, interest, and order among streetscape alternatives with form-based codes, traditional zoning codes, and no code applications. All three hypotheses were supported with surprising consistency in respondents' perceptions of beauty, interest, and order toward streetscape images with different code applications across the four locations. It is worth noting that the respondents appreciated the aesthetic design qualities brought to the streetscape images by the application of either control system.

The streetscapes with form-based codes were perceived as the most beautiful and interesting followed by the ones with zoning codes. Therefore, findings indicate that development of a model form-based code may enhance positive perceptions of beauty and interest across different downtown street signs. On the other hand, respondents' perception of order depended on landscape type, showing lower sense of order for form-based code applications in the corporate area (Node 3 Lansing Medical District), while higher sense of order in the downtown business area (Node 2 Lansing East Michigan Avenue).

Order, as represented in the study images, decreased when the alternative design created a bolder statement through signage. This pushing of the envelope was intentional as the Medical District (Node 3) had been identified as an area that local residents find sterile and confusing. In terms of order, respondents preferred the more routine, or familiar, signage that can be provided by a zoning standards system. The takeaway is either to be cautious in the creation of a form based code to provide users with some aspects of the familiar, especially order, or that bolder signage solutions may take time for users to adjust.

\section{Conclusion}

According to previous studies of Kim (2010), Morris et al. (2001), Rexhausen et al. (2012), and Snyder (2011), on-premise signs can have a direct economic impact on a business. This study broadens our understanding a bit 
to expand the knowledge base about the aesthetic impact of how signs are designed and constructed. Although, as Jourdan (2013) points out, model sign codes "cannot mandate good taste" (n.p.), they can encourage predictable built results by concentrating on the relationships of physical forms.

Cities around the world that are moving towards world class are dense, diverse and lively. They are also adaptable, reflexive and spontaneous (Witter \& Crawford, 2013). On-premise signage is one of the many site details that can support the growth of this new type of urban environment. However, creating pedestrian focused street signs, urban density, mixed-use buildings and aesthetic signage will require a means of crafting codes and regulating implementation which allows for new and contextually appropriate solutions. A form-based code system allows for creating a signage system that is focused on the "form" of the sign and its perceived aesthetic qualities. This is in contrast to traditional codes which are focused on the "function" of a sign. In this study, application of the Casper code allowed for expanding the options available for businesses to use signage as a part of their full communication system (to provide information and aesthetic elements) through fostering a human scale and feel to the streetscape. Another way of looking at a form-based signage code is that it allows for a conversation to be focused on the community's needs and desired vision, rather than on uniformity and elements which can be prescribed and quantified. For example, a form-based code can allow for building awnings, temporary placards, and window signs that are brought into the pedestrian scale, yet still provide functionally for vehicles.

A critical component of success for moving towards a form based code is to have a strong community vision. The vision creates the foundation of place making, fostering resilience, and building social capital (Place Shakers, 2013). Signage is an integral part of the vision - the physical, social and economic system of a city. As such, careful attention to this piece of the puzzle is a very achievable way of moving a community closer to reaching its full potential and a world class character.

\section{Limitations and Future Study}

Due to the lack of previous research on this topic, this study only begins to explore stakeholder perceptions of form-based signage within urban street signs. It is a beginning, and as with all research, refining and replicating the study will move us closer to filling in the knowledge gaps of commercial signage perceptions. The growing popularity of form-based codes requires more studies exploring the effects of these codes on various aspects of the built-environment as well as users' perceptions.

Although this study yielded some valuable findings, there are several limitations. The first limitation of the present study is potential bias and limited validity in the representation of signage code applications in using Sketch Up digital models to create alternative streetscape images for the comparisons. Every attempt was made to create sketches which represent applications of the form-based signage codes, zoning codes, and no signage code for the comparison images, but there are possibilities of different interpretations of sign design and sign codes. Therefore, careful consideration should be given when applying the findings of this study to different contexts.

Another potential limitation of this study is limited generalizability of findings. The size of the sample and non-probability sample of convenience could limit the generalizability of the findings. In addition, because the majority of participants were designers or planners, the sample may not be representative of the general population. It is recommended for future work to verify our study's findings in different locations, with a larger sample size, and by using a more effective sampling strategy.

Another approach that can be taken in immediate future research involves the further analysis of relationships among the three variables: sense of beauty, interest, and order. Since this study compared the two sign code applications, further exploration into correlations among the three variables and their effects on other aspects of participant perceptions toward street signs could be worthwhile. Additionally, this study focused on quantitative data. The further analyses of qualitative data in relation to the findings from the quantitative data may reveal more significant and meaningful findings.

\section{Acknowledgements}

This work was funded in part by the National Signage Foundation, Inc. Patty Herbin, SFI Senior Consultant, was instrumental in guiding the team through the research process, preparing the final report and presentation for the 2014 National Signage Education and Research Conference in Cincinnati, Ohio. An executive summary, "Stakeholder Perceptions of Form-Based and On-Premise Signage Codes in Streetscapes", is available at the SFI 
Research Library. http://www.thesignagefoundation.org/Library.aspx

\section{References}

Barnett, J. (2003). Redesigning Cities. Chicago: APA Planners Press.

Bungum, T., Meacham, M., \& Truax, N. (2007). The Effects of Signage and the Physical Environment on Stair Usage. Journal of Physical Activity \& Health, 4, 237-244.

Burdette, J. T. (2004). Form-Based Codes: A Cure for the Cancer Called Euclidean Zoning? Master's Thesis. http://scholar.lib.vt.edu/theses/available/etd-05122004-113700/unrestricted/BurdetteFINALmajorpaper.pdf

Carmona, M. (2009). Design Coding and the Creative, Market and Regulatory Tyrannies of Practice. Urban Studies, 46, 2643-2667. http://dx.doi.org/10.1177/0042098009344226

Chicago Metropolitan Agency for Planning (CMAP) (2013). Form-Based Codes: A Step-by-Step Guide for Communities. http://formbasedcodes.org/content/uploads/2013/11/CMAP-GuideforCommunities.pdf

City Data (2012) East Lansing, Michigan [Data File]. http://www.city-data.com/city/East-Lansing-Michigan.html

City of Lansing, Lansing Planning Office (2012). Design Lansing Comprehensive Plan. http://www.lansingmi.gov/media/view/Design Lansing Comprehensive Plan ADOPTED April 92012 LowRez/ $\underline{3523}$

Daley, V. L. M. (2010). Form-Based Codes: One Tool for Reviving Walkable Neighborhoods in Urban Areas. Thesis, Ithaca: Cornell University.

Dogu, U., \& Erkip, F. (2000). Spatial Factors Affecting Wayfinding and Orientation: A Case Study in a Shopping Mall. Environment and Behavior, 32, 731-755. http://dx.doi.org/10.1177/00139160021972775

East Lansing (2014). Code of Ordinances-Part II Chapter 32 Signs. https://www.municode.com/library/mi/east lansing/codes/code of ordinances?nodeId=PTIICOOR CH32SI

Ford, M. A., \& Torok, D. (2008). Motivational Signage Increases Physical Activity on a College Campus. Journal of American College Health, 57, 242-244. http://dx.doi.org/10.3200/JACH.57.2.242-244

Form-Based Codes Institute (2015). Form-Based Codes Defined. http://formbasedcodes.org/definition

Galindo, M. P. G., \& Rodríguez, J. A. C. (2000). Environmental Aesthetics and Psychological Wellbeing: Relationships between Preference Judgments for Urban Landscapes and Other Relevant Affective Responses. Psychology in Spain, 4, 1327.

Geller, R. S. (2010). Legality of Form-Based Zoning Codes. The Journal of Land Use \& Environmental Law, 26, 35-91.

Hansen, G. (2014). Design for Healthy Communities: The Potential of Form-Based Codes to Create Walkable Urban Streets. Journal of Urban Design, 19, 151-170. http://dx.doi.org/10.1080/13574809.2013.870466

Jourdan, D., Hurd, K., Hawkins, G., \& Winson-Geideman, K. (2013). Evidence-Based Sign Regulation: Regulating Signage on the Basis of Empirical Wisdom. Urban Lawyer, 45, 327-348.

Kaplan, R., \& Kaplan, S. (1989). The Experience of Nature: A Psychological Perspective. New York: Cambridge University Press.

Katz, P. (2005). Eight Advantages to Form Based Codes. Tampa, FL: City Government. http://www.tampagov.net/sites/default/files/land-development/files/Eight Advantages to Form.pdf

Kettren, L., Anderson, C., Bedell, J., Campbell, M., Freeman, W., Hoekstra, J., \& Meyer, P. L. (2010). Form Based Codes in 7 Steps. http://www.planningmi.org/downloads/fbc_guidebook_introduction_0.pdf

Kim, K. (2010). The Evaluation of the Impact of Form-Based Code and Conventional Zoning on Fort Mcpherson Redevelopment. Master's Thesis, Atlanta, GA: Georgia Institute of Technology.

https://smartech.gatech.edu/bitstream/handle/1853/34801/kim_keuntae_201008_mast.pdf?sequence=1

Kinoshita, Y., \& Orlando, C. C. (2013). Art of Signage: The Regulation of Outdoor Murals and the First Amendment. Cardozo Law Review, 35, 867-896.

Lang, J. T. (2005). Urban Design: A Typology of Procedures and Products. Amsterdam: Elsevier.

Lang, J. T. (2007). Urban Design as a Discipline and as a Profession. In M. Larice, \& E. Macdonald (Eds.), The Urban Design Reader (pp. 461-478). London: Routledge.

Lansing (2014). Code of Ordinances, Part 14-Building and Housing Code Title 4-Miscellaneous Building Regulations Chapter 1442-Signs.

https://www.municode.com/library/mi/lansing/codes/code of ordinances?nodeId=COOR PT14BUHOCO TIT4MIBUR $\underline{E}$

Lawlor, M. J. (2010). Gaining Ground in the Final Frontier: Surveying Legal Issues Raised by New England's Form-Based 
Codes. Urban Lawyer, 43, 839-848.

Liu, C., \& Burley, J. (2013). Landscape Evaluation Criteria: Dispersed Expectations. Modern Landscape Architecture. Proceedings of the 6th WSEAS International Conference on Landscape Architecture (LAÕ13), Nanjing, 17-19 November 2013, 19-23.

Matsuoka, R. H., \& Kaplan, R. (2008). People Needs in the Urban Landscape: Analysis of Landscape and Urban Planning Contributions. Landscape and Urban Planning, 84, 7-19. http://dx.doi.org/10.1016/j.landurbplan.2007.09.009

Morris, M., Hinshaw, M., Mace, D., \& Weinstein, A. (2001). Context-Sensitive Signage Design. Chicago, IL: American Planning Association. https://www.planning.org/research/signs/pdf/contextsensitivesignagedesign.pdf

Nohl, W. (2001). Sustainable Landscape Use and Aesthetic Perception-Preliminary Reflections on Future Landscape Aesthetics. Landscape and Urban Planning, 54, 223-237. http://dx.doi.org/10.1016/S0169-2046(01)00138-4

O’Neill, M. J. (1991). Effects of Signage and Floor Plan Configuration on Wayfinding Accuracy. Environment and Behavior, 23, 553-574. http://dx.doi.org/10.1177/0013916591235002

Palmer, J. F. (2000). Reliability of Rating Visible Landscape Qualities. Landscape Journal, 19, 166-178.

Parolek, D., Parolek, K., \& Crawford, P. (2008) Form-Based Codes: A Guide for Planners, Urban Designers, Municipalities, and Developers. Hoboken, NJ: John Wiley \& Sons Inc.

Place Shakers (2013). Ways to Fail at Form-Based Codes 01: Don't Articulate a Vision. http://www.placemakers.com/2013/02/21/ways-to-fail-at-form-based-codes-01/

Portella, A. A. (2007). Evaluating Commercial Signs in Historic Streetscapes: The Effects of the Control of Advertising and Signage on User's Sense of Environmental Quality. Ph.D. Thesis, Oxford: Oxford Brookes University. http://discovery.ucl.ac.uk/10817/

Portella, A. A. (2014). Visual Pollution: Advertising, Signage and Environmental Quality. Surrey: Ashgate Pub.

Power, M. (2007). Beyond Zoning: Home Builders Seek Relief. Professional Builder. http://www.probuilder.com/beyond-zoning-home-builders-seek-relief

Purdy, J. R. (2006). Smart-Growth Tactics: Form-Based Codes, New Approaches to Zoning. Michigan Association of Planning. https://www.mml.org/pdf/map article issue28.pdf

Rangwala, K. (2012). Form-Based Codes. Economic Development Journal, 11, 35-40. http://ezproxy.msu.edu/login?url=http://search.proquest.com/docview/1124470686?accountid=12598

Real, E., Arce, C., \& Sabucedo, J. M. (2000). Classification of Landscapes Using Quantitative and Categorical Data, and Prediction of Their Scenic Beauty in North-Western Spain. Journal of Environmental Psychology, 20, 355-373. http://dx.doi.org/10.1006/jevp.2000.0184

Rexhausen, J., Hildebrandt, G., \& Auffrey, C. (2012). The Economic Value of On-Premise Signage (SFI Research Report). Washington DC: The Signage Foundation, Inc. http://www.thesignagefoundation.org/Portals/0/EVOSFINALAugust2012.pdf

Sanford, J., \& Finlay, T. (1988). The Effects of Exhibit Signage on Visitor Behavior. Nineteenth Annual Conferences of the Environmental Design Research Association, 19, 243-257. http://www.edra.org/sites/default/files/publications/EDRA19-Sanford-243-247.pdf

Scott, A. (2002). Assessing Public Perception of Landscape: The Landmap Experience. Landscape Research, 27, $271-295$.

Senbel, M., van der Laan, M., Kellett, R., Girling, C., \& Stuart, J. (2013). Can Form-Based Code Help Reduce Municipal Greenhouse Gas Emissions in Small Towns? The Case of Revelstoke, British Columbia. Canadian Journal of Urban Research, 22, 72-92.

Sieferle, R. P. (1986). Entstehung und Zerstörung der Landschaft. In P. Smuda (Ed.), Frankfurt/M: Landschaft, 238-265.

Simpson, S. (2010). A Sense of Place: Can Form-Based Code Planning Contribute to the Public Realm of Prince Avenue? $\mathrm{PhD}$ Thesis, Athens, GA: University of Georgia. https://getd.libs.uga.edu/pdfs/simpson_scott_a_201005_mla.pdf

Smardon, R. C., Palmer, J. F., \& Felleman, J. P. (1986). Foundations for Visual Project Analysis. New York: Wiley. http://dx.doi.org/10.1080/01426390220149520

Snyder, J. (2011). Beyond Aesthetics: How Billboards Affect Economic Prosperity. (Research Report). Washington DC: Scenic America. http://www.scenic.org/storage/PDFs/Beyond_Aesthetics.pdf

Stamps, A. E. (2004). Mystery, Complexity, Legibility and Coherence: A Meta-Analysis. Journal of Environmental Psychology, 24, 1-16. http://dx.doi.org/10.1016/S0272-4944(03)00023-9

Turley, L. W., \& Milliman, R. E. (2000). Atmospheric Effects on Shopping Behavior: A Review of the Experimental Evidence. Journal of Business Research, 492, 193-211. http://dx.doi.org/10.1016/S0148-2963(99)00010-7

Tzeng, S. Y., \& Huang, J. S. (2009). Spatial Forms and Signage in Wayfinding Decision Points for Hospital Outpatient Services. Journal of Asian Architecture and Building Engineering, 8, 453-460. http://dx.doi.org/10.3130/jaabe.8.453 
United States Bureau of Labor Statistics (2014). Economy at a Glance: Lansing-East Lansing, MI [Data file]. http://www.bls.gov/eag/eag.mi_lansing_msa.htm

Vilar, E., Rebelo, F., \& Noriega, P. (2012). Indoor Human Wayfinding Performance Using Vertical and Horizontal Signage in Virtual Reality. Human Factors and Ergonomics in Manufacturing \& Service Industries, 24, 601-615. http://dx.doi.org/10.1002/hfm.20503

Walters, D. (2011). Smart Cities, Smart Places, Smart Democracy: Form-Based Codes, Electronic Governance and the Role of Place in Making Smart Cities. Intelligent Buildings International, 3, 198-218. http://dx.doi.org/10.1080/17508975.2011.586670

Wei, L. L. W. (2011). Function Follows Form: Study on American Form-Based Codes. Modern Urban Research, 3, 38-42.

Witter, S., \& Crawford, P. (2013). Creating a World Class Community. East Lansing, MI: School of Planning, Design \& Construction, Michigan State University. 